\title{
Teacher assessment of simulation-based serious games for science education
}

\author{
Seungho Baek ${ }^{1}$, Ji-Young Park ${ }^{1}$, JungHyun Han1 * \\ 1 First Author, *corresponding Korea University, \\ \{bshsqa, lemie, jhan\}@korea.ac.kr
}

\begin{abstract}
This paper presents serious games developed for the science subject in elementary and middle schools, specifically on the three topics of "Force and Motion," "State Change of Water," and "Earth and Moon." The PC game "Force and Motion" implemented frictional/gravitational/magnetic force simulations, in the mobile game "State Change of Water," particle-based fluid simulations were implemented, and in the PC- and mobile-based multi-platform game "Earth and Moon," a solar system simulation was implemented. In order to find out the essential components for the science educational games, the components of each topic were thoroughly analyzed, and then a game-based curriculum was developed for the components classified as having high-or mid-level difficulties in both teaching and learning. Based on the curriculum, the three games were created. The games were evaluated by elementary and middle school teachers, and the evaluation results showed that simulation-based serious games are promising tools for improving learning effects in science-related subjects.
\end{abstract}

Keywords: serious games, simulation, science education;

\section{Introduction}

The usefulness of serious games has been proved in many fields including education, training, and healthcare. In fact, serious games are currently being used in the real world education fields, and it is agreed upon that they are especially effective in motivating learners. For example, regarding the subjects of mathematics and foreign languages, many commercial games are available. However, the educational potential of serious games has not yet been proved on scientific subjects. There would be many reasons behind this lack of proof, but the most important reason would be that games concerning scientific subjects require physically-based simulation, which is hard to implement for real-time application especially the non-rigid objects.

This paper presents serious games developed for scientific subjects in elementary and middle schools. Unlike the previous games that largely focused on visual effects rather than physically correct simulations and consequently would often lead students to fatal misconceptions, the serious games presented in this paper are intended to be faithful to the physics laws: in the PC-based game "Force and Motion" frictional/gravitational/magnetic force simulations were implemented, in the mobile game "State Change of Water," particle-based fluid simulation was implemented, and in the PC- and mobile-based multi-platform game "Earth and Moon," solar system simulation was implemented. The games were evaluated by elementary and middle school teachers, and the evaluation results show that simulation based serious games are promising tools for improving the learning effects in science subject.

This paper is organized as follows. Section 2 reviews the related studies. Section 3 gives an overview of how the games have been designed and developed. Sections 4, 5, and 6 detail "Force and Motion," "State Change of Water," and "Earth and Moon," respectively. Section 7 presents the evaluation results, and Section 8 concludes the paper. 


\section{Related work}

The status of serious games in the history of game development has been studied in Zyda [1]. With the advent of Nintendo Wii and Wii Fit, the integration of home video games and fitness or healthcare is now taken for granted [2]. Research on the potential of serious games in rehabilitation training [3,4,5] confirms their effectiveness, and Sánchez and Olivares [6] and Mouaheb et al. [7] discussed serious games as an education tool.

Various research works reported that computer or video games are actually effective in boosting learning effects. Connolly et al. [8] have proved that serious games can lead to positive functional development, and De and Jarvis [9] have shown improvement of education/training effects with the use of serious games. Wrzesien and Raya [10] applied interactive game content to science education and investigated its effectiveness. Yusoff et al. [11] studied the design trend of serious games. Roungas and Dalpiaz [12] proposed model-driven framework to reduce problem of game development documents

Lee and Doh [13] used an English-learning game to find out possibilities of serious games as a tool of encouraging emotional engagement. Yang et al. [14] proposed effective English vocabulary learning system with repetitive and rate-matching rules that is commonly used in game. Coller and Scott [15] showed the effectiveness of video games in teaching mechanical engineering to undergraduate students by comparing it to the effectiveness of traditional lecture/textbook-based teaching. Pope and Mangram [16] found that math games significantly increased the sense of numbers for elementary school students. Wouter et al. [17] promoted mathematical learning by using emotional conditions such as surprise.

\section{Game design and development}

The research and development efforts presented in this paper were conducted on three topics of the science subject in elementary and middle schools: "Force and Motion," "State Change of Water," and "Earth and Moon." To develop serious games for scientific learning, analyzing the components of the topics is essential. Given the standards of assessing learning achievement, we estimated the teaching-learning difficulty of each component. The teaching-learning difficulty is classified as either high, mid, or low. Table 1 shows the analysis results for "Force and Motion."

When estimating the teaching-learning difficulty, many factors were taken into consideration. Factors regarding if a component contains abstract concepts which are far-fetched from everyday life, if it requires the students to comprehend the time-spatial relationships, if it requires to conduct experiments which are actually hard to implement and etc. A team of elementary and middle school teachers and professors of educational institutes participated in the process, making the estimated difficulties highly acceptable in the community.

For the components classified as having high- or mid-level difficulties, the team of teachers and professors worked with the game designers to develop a game-based curriculum. To do this, the goal of a game was defined first and then the scenario was designed. The focus was not only on the the motivation for learning and the learning effects but also on enhancing the visual realism. The selected three topics are of mid- to high-level difficulties. If other topics of the curriculum have difficult components, they can also be suitable for serious game contents.

\section{4. "Force and motion"}

"Force and Motion" is a 3D PC-based game, where students can learn the principles of the gravitational, frictional, and magnetic forces. The game is a roller coaster game which consists of three stages. The user can move on to the next stage only when the current stage's mission is completed. In the first stage, "The Rift of Dwarves" shown in Figure 1-(a), the train can advance forward by solving a series of quizzes about force and motion. In this stage, the users should apply their prior knowledge to solve the quizzes. When they fail to solve a quiz, a couple of hints are provided.

The second stage is named "The Gold Mine of the Owl King," where a user navigates a sleigh on the rail. The rail has a complex structure: some parts of the rail are straight but others are curved, even including $360^{\circ}$ circular path. While navigating through a series of milestones, the user's 
Table 1.Analysis of the components in "Force and Motion" topic.

\begin{tabular}{|c|c|c|c|c|c|c|}
\hline \multirow{2}{*}{$\begin{array}{l}\text { Goals for } \\
\text { education } \\
\text { curriculum }\end{array}$} & \multirow{2}{*}{$\begin{array}{c}\text { Achievement } \\
\text { standard }\end{array}$} & \multirow{2}{*}{$\begin{array}{c}\text { Achievement } \\
\text { standard details }\end{array}$} & \multicolumn{3}{|c|}{$\begin{array}{c}\text { Teaching-learning } \\
\text { difficulty }\end{array}$} & \multirow{2}{*}{$\begin{array}{c}\text { Game } \\
\text { development } \\
\text { method }\end{array}$} \\
\hline & & & high & mid & low & \\
\hline \multirow{3}{*}{$\begin{array}{l}\text { Understanding } \\
\text { that, between } \\
\text { magnets, there } \\
\text { are attractive and } \\
\text { repulsive forces. } \\
\text { Activity: find } \\
\text { magnetic poles }\end{array}$} & \multirow{3}{*}{$\begin{array}{l}\text { Can find } \\
\text { magnetic poles } \\
\text { and explain the } \\
\text { attractive and } \\
\text { repulsive forces }\end{array}$} & $\begin{array}{l}\text { Can classify } \\
\text { objects into those } \\
\text { attracted to a } \\
\text { magnet and those } \\
\text { not }\end{array}$ & & & $\bigcirc$ & $\begin{array}{l}\text { Actual experiment } \\
\text { is more } \\
\text { appropriate. Not } \\
\text { fit for game }\end{array}$ \\
\hline & & $\begin{array}{c}\text { Can find magnetic } \\
\text { poles }\end{array}$ & & $\bigcirc$ & & \multirow{2}{*}{$\begin{array}{l}\text { Using a magnet's } \\
\text { attractive and } \\
\text { repulsive forces, } \\
\text { obtain a game } \\
\text { item or evade a } \\
\text { monster }\end{array}$} \\
\hline & & $\begin{array}{l}\text { Can explain the } \\
\text { forces that exist } \\
\text { between opposite } \\
\text { poles and same } \\
\text { poles }\end{array}$ & & 0 & & \\
\hline \multirow{2}{*}{$\begin{array}{l}\text { Understanding } \\
\text { the magnetic } \\
\text { feature of } \\
\text { pointing towards } \\
\text { a certain } \\
\text { direction. } \\
\text { Activity: make a } \\
\text { compass }\end{array}$} & \multirow[b]{2}{*}{$\begin{array}{c}\text { Can explain a } \\
\text { magnet has the } \\
\text { property of } \\
\text { pointing towards } \\
\text { a certain direction }\end{array}$} & $\begin{array}{c}\text { Can find a } \\
\text { magnet's direction }\end{array}$ & 0 & & & $\begin{array}{l}\text { Find directions } \\
\text { using a magnet }\end{array}$ \\
\hline & & $\begin{array}{c}\text { Can make a } \\
\text { compass with a } \\
\text { magnetized nail }\end{array}$ & & & & $\begin{array}{l}\text { Make a compass } \\
\text { using } \\
\text { magnetizable } \\
\text { objects }\end{array}$ \\
\hline $\begin{array}{l}\text { Making a tool or } \\
\text { toy using } \\
\text { magnetic } \\
\text { properties. } \\
\text { Activity: make a } \\
\text { toy using } \\
\text { magnets }\end{array}$ & $\begin{array}{c}\text { Can make a tool } \\
\text { or toy using } \\
\text { magnets }\end{array}$ & $\begin{array}{c}\text { Can design and } \\
\text { develop a toy that } \\
\text { uses magnet }\end{array}$ & & & & $\begin{array}{l}\text { Using magnets, } \\
\text { land from high } \\
\text { altitude }\end{array}$ \\
\hline $\begin{array}{l}\text { Finding } \\
\text { examples for the } \\
\text { usage of } \\
\text { magnets in daily } \\
\text { environment }\end{array}$ & $\begin{array}{c}\text { Can give } \\
\text { examples for the } \\
\text { usage of magnets } \\
\text { in daily } \\
\text { environment }\end{array}$ & $\begin{array}{c}\text { Can find examples } \\
\text { for the usage of } \\
\text { magnets in daily } \\
\text { environment }\end{array}$ & & $\bigcirc$ & & $\begin{array}{l}\text { Using a magnet, } \\
\text { find objects. }\end{array}$ \\
\hline
\end{tabular}

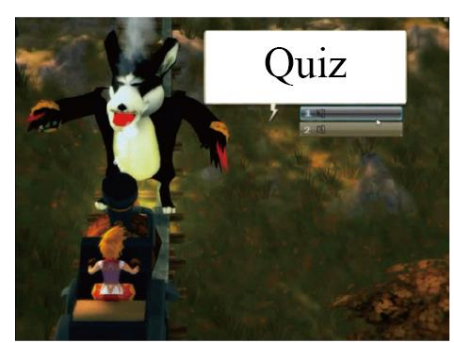

(a)

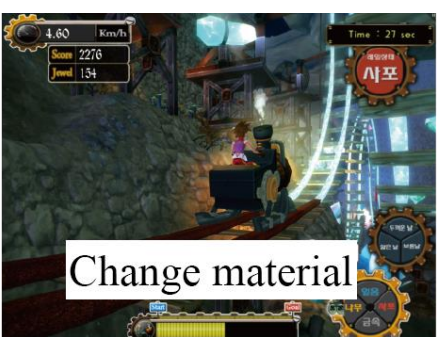

(b)

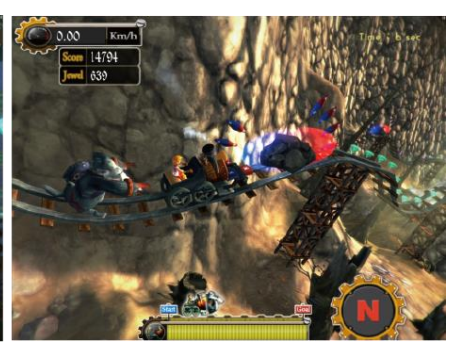

(c)

Figure 1. Screen shots of "Force and Motion." (a) The first stage for quiz. (b) The second stage for learning the frictional and gravitational forces. (c) The third stage for learning the magnetic forces. 
mission is to pass through a milestone within a certain range of time. The rail's material dynamically changes into ice, metal, or wood. Furthermore, the user can select the material of the sleigh runners among ice, metal, wood, and sand paper so as to adjust the frictional force, control the sleigh speed, and complete the missions on milestones. In addition, the width of the sleigh runners can be adjusted by the user. The wider, the more frictional force. See Figure 1-(b) for the screen shot of the second stage.

The user may go through a trial-and-error loop. For example, the combination of ice rail and ice runners would make the sleigh overly fast, which would make it harder for the user to complete the mission. In contrast, the combination of wood rail and sand-paper runners would make the sleigh overly slow, even making the sleigh fall off the rail for the case of $360^{\circ}$ circular path. While completing the stage, the user can gradually overcome misconceptions and eventually embrace the correct concepts. The user will be able to learn the frictional properties of the materials seen in everyday life and how the frictional forces change according to the contact areas.

In the third stage, "The Orange Mountain Range," the user will learn the magnetic forces. Many obstacles are on the rail itself. They are all magnetic rocks. The north and south poles of an obstacle are visualized using red and blue colors, respectively, which are quite familiar to students. In addition, the magnetic field induced by each obstacle can be inferred from compasses, which are scattered around the obstacle. The obstacles can be cleared away by using the huge bar magnet attached in front of the sleigh. It can be rotated by the user. If the north pole of an obstacle faces the sleigh, for example, the user should rotate the bar magnet such that its north pole faces the obstacle. Then, the repulsive force between them pushes the obstacle away. Otherwise, the sleigh will crash into the obstacle. Figure 1-(c) shows the screen shot of the third stage.

"Force and Motion" was developed using Unity, a game development tool. In Unity, users can write a script describing the behavior of an object. For example, a magnet's behavior [18] caused by other magnets is described in a script, which computes the force and torque acting on the magnet. Then, Unity's internal rigid-body simulation module moves the magnets as described by the script.

\section{5. "State change of water"}

"State Change of Water" is a 2D game which is available on smart mobile devices such as smart phones and tablets. The goal of the game is to control the water flow so as to preserve as much water as possible till the final destination. The game provides an intuitive and simple interface. For example, the water flow can be controlled by tilting the device, as shown in Figure 2-(a).

In addition, the game is intended for effectively relaying the learning content about the properties of water, such as the state changes among ice, water, and vapor. If the water follows a path with many holes or flows over a porous object, for example, the user can decrease the temperature below zero and freeze the water, as illustrated in Figure 2-(b), to avoid holes or porous objects. In contrast, when a volcanic region is chosen at a branch point, for example, the water would evaporate, as shown in Figure 2-(c). It would make it harder for the user to successfully complete the mission.

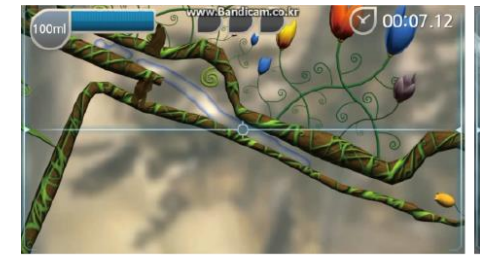

(a)

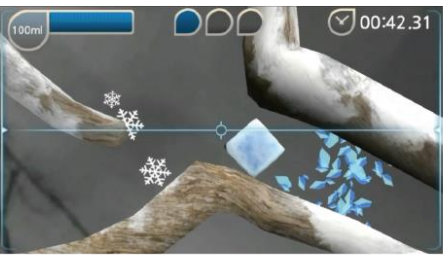

(b)

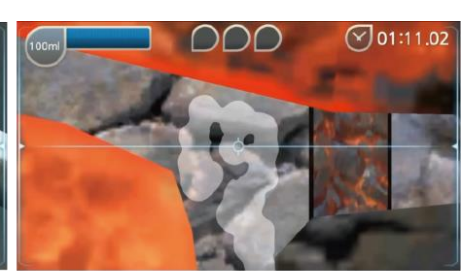

(c)

Figure 2. Screen shots of "State Change of Water." (a) Water. (b) Ice. (c) Vapor. 


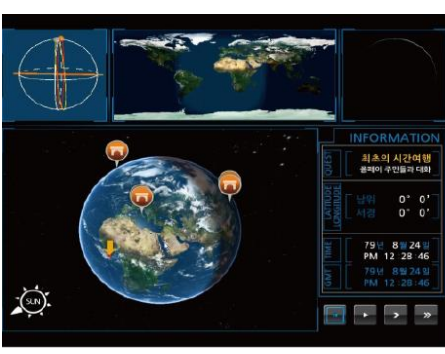

(a)

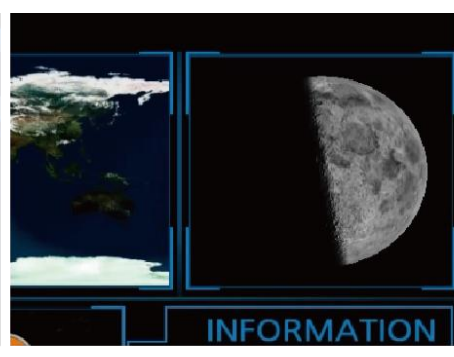

(b)

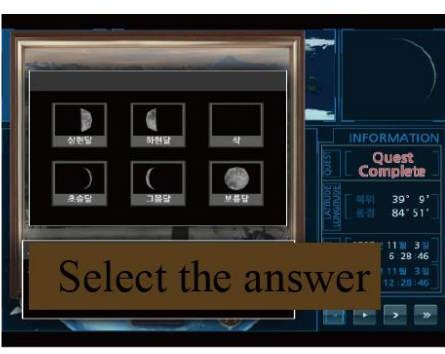

(c)

Figure 3. Screen shots of "Earth and Moon." (a) Game interface. (b) Change of the moon phase.

(c) Mission progress.

This game was developed using the particle-based fluid simulation method [19], which was implemented also in Unity scripts. Both water and vapor are simulated as particles whereas ice is simulated as a rigid body. Fluid simulation requires a lot of computation time and it is currently impossible to implement real-time 3D fluid simulation at mobile devices. That is why we adopted 2D fluid simulation.

\section{6. "Earth and moon"}

"Earth and Moon" is a solar system simulation game based on both PC and mobile devices. The goal of the game is to complete moon-related missions by navigating time and space where the famous historical events happened. Figure 3-(a) shows the game interface. It consists of five windows, from the top-left, position of the moon revolving around the earth, day/night map over time, moon phase on the date, the earth view with selected locations visualized, and date/location slots.

An example of the game scenario is as follows: Students are asked to select a specific date and location of a historical event such as when and where Thomas Edison was born. Then, the moon phase at the chosen date and location is visualized, as shown in Figure 3-(b). Then, a quiz is given to the students, e.g., What would be the moon phase 19 days later? Some hints are provided if the students cannot solve the quiz. Figure 3-(c) shows the quiz stage.

"Earth and Moon" was developed using the real celestial body information with Unity scripts. This game was built upon not only PC but also smart mobile devices. Touch and haptic interfaces of the mobile devices neatly support the interface functions.

\section{Evaluation}

In order to evaluate the value of the developed games as actual teaching materials, uninstructive parts also must be evaluated along with instructive parts. However, it is definitely difficult to find these uninstructive parts by using student assessment because some of the uninstructive elements of game include attractive components like violence [20]. Therefore, developed games, "Force and Motion," "State Change of Water," and "Earth and Moon," were assessed by the teachers using the tool proposed by Jung et al. [21]. The elements of the tool were designed to assess the educational potential of serious games. Each element was classified into one of the five categories, following the evaluation purpose. The participants first played the three games and then scored each element of Table 2 on the scale of 1 to 4 . By analyzing the survey, the scores can be used not only to check the quality of the game and how the game can promote learning but also to extract further information to reduce the suggestive and violent contents that could hinder learning.

In each of "State Change of Water," "Earth and Moon," and three stages of "Force and Motion," a group of science class teachers was involved: 7 teachers in "The Rift of Dwarves," 6 in "The Gold Mine of the Owl King," 8 in "The Orange Mountain Range," 4 in "State Change of Water," and 8 in "Earth and Moon." After playing the games, the subjects were asked to rate from one to four on each evaluation element. The evaluation results are shown in Table 3. The teachers also provided comments on the strengths and weaknesses of the games and how to improve the games. 
Table 2. The elements to be evaluated for serious games.

\begin{tabular}{|c|c|}
\hline evaluation area & evaluation elements \\
\hline $\begin{array}{l}\text { teaching-learning } \\
\text { contents }\end{array}$ & $\begin{array}{l}\text { validity of purpose, } \\
\text { validity of contents, } \\
\text { practicality of contents, } \\
\text { reliability of contents, } \\
\text { systemicity of contents, } \\
\text { appropriacy of quantity }\end{array}$ \\
\hline $\begin{array}{l}\text { teaching-learning } \\
\text { strategy }\end{array}$ & $\begin{array}{c}\text { motivation, } \\
\text { learner control, feedback, } \\
\text { consideration of learner level, } \\
\text { system to help learning }\end{array}$ \\
\hline screen organization & $\begin{array}{l}\text { appropriacy of design, } \\
\text { freshness of design, } \\
\text { convenience of design }\end{array}$ \\
\hline technology & $\begin{array}{l}\text { systemicity of management, } \\
\text { security }\end{array}$ \\
\hline economics-morality & $\begin{array}{l}\text { copyright protection, } \\
\text { human rights protection, } \\
\text { personal information protection, } \\
\text { economics }\end{array}$ \\
\hline
\end{tabular}

Table 3. Evaluation results.

\begin{tabular}{|c|c|c|c|c|c|c|c|}
\hline \multicolumn{7}{|c|}{ average scores } & \multirow[b]{2}{*}{ average } \\
\hline \multicolumn{2}{|c|}{ games } & teaching & teaching & screen & to & economics- & \\
\hline \multirow{3}{*}{$\begin{array}{l}\text { Force } \\
\text { and } \\
\text { Motion }\end{array}$} & $\begin{array}{l}\text { The Rift of } \\
\text { Dwarves }\end{array}$ & 2.31 & 3.00 & 2.33 & 3.00 & 2.65 & 2.89 \\
\hline & $\begin{array}{l}\text { The Gold } \\
\text { Mine of the } \\
\text { Owl King }\end{array}$ & 1.62 & 2.60 & 2.33 & 3.50 & 2.26 & 2.44 \\
\hline & $\begin{array}{c}\text { The Orange } \\
\text { Mountain } \\
\text { Range }\end{array}$ & 1.62 & 2.40 & 2.00 & 3.00 & 2.15 & 2.44 \\
\hline \multicolumn{2}{|c|}{$\begin{array}{c}\text { State Change of } \\
\text { Water }\end{array}$} & 2.56 & 2.15 & 2.40 & 3.00 & 3.00 & 2.47 \\
\hline \multicolumn{2}{|c|}{ Earth and Moon } & 2.78 & 1.85 & 2.60 & 2.33 & 3.25 & 2.41 \\
\hline \multicolumn{2}{|c|}{ average } & 2.18 & 2.40 & 2.33 & 2.97 & 2.66 & \\
\hline
\end{tabular}

The evaluation results indicate that the teaching-learning content requires improvement in general. "The Gold Mine of the Owl King" and "The Orange Mountain Range" scored the lowest whereas "The Rift of Dwarves," "State Change of Water," and "Earth and Moon" scored above 2. The teachers commented that the curriculum is well organized and adheres well to the content to be learned. However, they advised that, in "The Orange Mountain Range," the directions given to the users be made clearer and the sleigh speed control in "The Gold Mine of the Owl King" be made both more realistic and more intuitive.

Regarding the teaching-learning strategy, "The Rift of Dwarves," "The Gold Mine of the Owl King," and "The Orange Mountain Range" scored relatively high, but "Earth and Moon" and "State Change of Water" scored low. The scenarios of all games were highly evaluated, but the teachers advised that some game features such as monotonous background music, the overall difficulty, and low rewarding system be improved.

The screen organization scored below 2.5. The reasons for such low scores have been analyzed to be the low quality of the graphics and inconvenient user interfaces compared to those of 
commercial games. These would be the inherent weakness of the prototype games, but the evaluation results imply that serious game developers should put more efforts into the graphics and user interfaces.

The average score of the technology element is 2.97 , which is the highest among the evaluation elements. It was not unexpected because frictional/magnetic forces and particle-based fluid simulations are novel techniques, which are hard to find even in commercial games.

The economics-morality element also scored high. It was because the games were made free and available to all users who can access and download the games through Internet. However, the elementary school teachers advised that the game character's animation and costumes should be made more appropriate for elementary school students.

\section{Conclusion}

This paper presented serious games developed for the science subject in elementary and middle schools: "Force and Motion," "State Change of Water," and "Earth and Moon." The games were evaluated by teachers. The evaluation results showed the potential of serious games in science subject and also their limitations. For example, the teachers' comments that the game-based curriculum is well organized and adheres well to the content to be learned imply the potential of serious games as a complementary tool for science education. On the other hand, to motivate the learners in elementary and middle schools, serious game developers should put more efforts into low-rated aspects, i.e. game organization, user interface, and the graphics.

\section{Acknowledgments.}

This work was supported by Institute for Information \& communications Technology Promotion(IITP) grant funded by the Korea government(MSIP) (No.R0115-15-1011, Physics-based solutions for science experiments in e-Book)

\section{References}

[1] Zyda, M., From visual simulation to virtual reality to games: Computer, Vol. 38, Nr. 9, September 2005.

[2] Göbel, S., Hardy, S., Wendel, V., Mehm, F., "Steinmetz, R., Serious games for health: Personalized exergames". In Proceedings of the International Conference on Multimedia, ACM, 2010.

[3] Kang, S., Jung, S., Development of a Serious Game for Rehabilitation Training using 3D Depth Camera: Journal of Korea Game Society, Vol. 13, Nr. 1, February 2013.

[4] Kim, Y.S., Kim, N.Y., Cho, S.H., A study on the positive impact of a persuasive game and its potential for social change literacy: Journal of Korea Game Society, Vol. 14, Nr. 1, February 2014.

[5] Kim, K., Lee, Y., Oh, S., Development and analysis of a walking game 'paldokangsan3'using kinect: Journal of Korea Game Society, Vol. 14, Nr. 1, February 2014.

[6] Sánchez, J., Olivares, R., Problem solving and collaboration using mobile serious games: Computers \& Education, Vol. 57, Nr. 3, November 2011. http://dx.doi.org/10.1016/j.compedu.2011.04.012

[7] Mouaheb, H., Fahli, A., Moussetad, M., Eljamali, S., The serious game: what educational benefits?: Procedia-Social and Behavioral Sciences, Vol. 46, Nr. 0, September 2012. http://dx.doi.org/10.1016/j.sbspro.2012.06.465

[8] Connolly, T.M., Boyle, E.A., MacArthur, E., Hainey, T., Boyle, J.M., A systematic literature review of empirical evidence on computer games and serious games: Computers \& Education, Vol. 59, Nr. 2, September 2012. http://dx.doi.org/10.1016/j.compedu.2012.03.004

[9] De Freitas, S., Jarvis, S., Serious games-engaging training solutions: A research and development project for supporting training needs: British Journal of Educational Technology, Vol. 38, Nr. 3, April 2007. http://dx.doi.org/10.1111/j.1467-8535.2007.00716.x 
[10] Wrzesien, M., Raya, M.A., Learning in serious virtual worlds: Evaluation of learning effectiveness and appeal to students in the e-junior project: Computers \& Education, Vol. 55, Nr. 1, August 2010. http://dx.doi.org/10.1016/j.compedu.2010.01.003

[11] Yusoff, A., Crowder, R., Gilbert, L., "Validation of serious games attributes using the technology acceptance model". In Games and Virtual Worlds for Serious Applications Second International Conference on, IEEE, 2010. http://dx.doi.org/10.1109/VS-GAMES.2010.7

[12] Roungas, B., Dalpiaz, F., A Model-Driven Framework for Educational Game Design: Games and Learning Alliance, Vol. 9599, Nr. 1, 2016.

[13] Lee, H., Doh, Y., A Study on Enhancing Emotional Engagement in Learning Situation- Based on Development Case of English Learning Serious Game ‘Word Collectrian': Journal of Korea Game Society, Vol. 12, Nr. 6, December 2012.

[14] Yang, J., Oh, K., Youm, K., English Vocabulary Learning System Based on Repetitive Learning and Rate-Matching Rule: Games and Learning Alliance, Vol. 9599, Nr. 1, 2016.

[15] Coller, B.D., Scott, M.J., Effectiveness of using a video game to teach a course in mechanical engineering: Comput. Educ., Vol. 53, Nr. 3, November 2009. http://dx.doi.org/10.1016/j.compedu.2009.05.012

[16] Pope, H., Mangram, C., Wuzzit Trouble: The Influence of a Digital Math Game on Student Number Sense: International Journal of Serious Games, Vol. 2, Nr. 4, December 2015.

[17] Wouters, P., Oostendorp, H., Vrugte, J., The Role of Surprise in Game-Based Learning for Mathematics: Games and Learning Alliance, Vol. 9599, Nr. 1, 2016.

[18] Thomaszewski, B., Gumann, A., Pabst, S., Straßer, W., Magnets in motion: ACM Transactions on Graphics, Vol. 27, Nr. 5, December 2008. http://dx.doi.org/10.1145/1457515.1409115

[19] Muller, M., Charypar, D., Gross, M., "Particle-based fluid simulation for interactive applications". In Proceedings of the 2003 ACM SIGGRAPH/Eurographics Symposium on Computer Animation, Eurographics Association, 2003.

[20] Lee J., Lee H., A Study on Balancing of the Positive and Negative Functions of Games: The Korean Journal of animation, Vol. 8, Nr. 1, 2012.

[21] Jung, H., Lee, C., Jhun, Y., Development and application of an evaluation tool for serious games: Journal of The Korean Association of Information Education, Vol. 18, Nr. 3, September 2014. 